\title{
Morphology and function of the reproductive tract of the spider crab Libinia spinosa (Crustacea, Brachyura, Majoidea): pattern of sperm storage
}

\author{
M. P. Sal Moyano • M. A. Gavio • E. I. Cuartas
}

Received: 5 June 2009/Revised: 6 November 2009/Accepted: 9 November 2009/Published online: 28 November 2009

(C) Springer-Verlag and AWI 2009

\begin{abstract}
Morphology and function of the male reproductive tract, female spermatheca and patterns of sperm storage were assessed in the crab Libinia spinosa using histological methods. Testes are characterized by the presence of peripheral spermatogonia and different sequences of sperm maturity. Spermatophores begin to be packed in the last portion. The vas deferens consists of three sections: anterior, with undeveloped spermatophores and free sperm; median, with well-developed spermatophores; and posterior with granular secretions. Female spermathecae are of the ventral type, with a velum separating dorsal and ventral chambers. Live individuals were kept in the laboratory and arranged in pairs. An experiment was conducted toward the end of the reproductive season, in which males with the right gonopod excised were placed with receptive females. After mating, females were killed and the spermathecae dissected for histological study and observation of the pattern of sperm storage. Spermatozoa were found forming discrete sperm packages. New ejaculates can fill the entire spermatheca or be restricted to the ventral chamber; sperm are rounded, with a distinguishable acrosomal core. Old ejaculates are restricted to the dorsal chamber and are of irregular shape and larger size; an
\end{abstract}

Communicated by H.-D. Franke.

M. P. Sal Moyano - M. A. Gavio - E. I. Cuartas Departamento de Biologia, Estación Costera J. J. Nágera, Facultad de Ciencias Exactas y Naturales, Universidad Nacional de Mar del Plata, Funes 3350,

7600 Mar del Plata, Argentina

M. P. Sal Moyano $(\varangle)$

CONICET, Consejo Nacional de Investigaciones Científicas y Técnicas, Buenos Aires, Argentina

e-mail: salmoyan@mdp.edu.ar; mariapaz99@hotmail.com acrosomal core was not distinguishable. The secretions produced by the glandular epithelium of the dorsal chamber of the spermathecae are likely to have a role in the removal of dead sperm.

Keywords Testes · Vas deferens - Spermatheca · Histology $\cdot$ Crustacea

\section{Introduction}

Mating in brachyuran crabs has attracted considerable recent attention, as its complexity and diversity provide the opportunity to investigate hypotheses on mating systems and cryptic sexual selection. The brachyuran female reproductive tract is composed of paired ovaries, oviducts, spermathecae, vaginas and vulvas (Hartnoll 1968). Spermathecae are structures functioning in sperm retention after mating. Diesel (1991) defined ventral and dorsal types according to the topology of the connection to the ovary. In the ventral type, the oviduct abuts in the ventral area of the receptacle, close to the vagina's ventral opening. In the dorsal type, the oviduct abuts in the dorsal area of the receptacle, and is widely separated from the vagina's ventral opening. Seminal receptacles play a key role in the reproductive behavior of the spider crabs (Majoidea sensu $\mathrm{Ng}$ et al. 2008; Beninger et al. 1988; Diesel 1989, 1991; Sainte-Marie and Lovrich 1994), allowing the sperm from one or more copulas from several males to be stored (González-Gurriarán et al. 1998). Whether the oviduct and the vagina are in close proximity to each other has important implications for mating. Last-male sperm precedence was considered by Diesel (1991), who hypothesized that in the case of the ventral type, the last male in copulating is the first to fertilize the oocytes, as previous 
ejaculates are displaced dorsally; in dorsal types, by contrast, the first male in copulating would be the one who fertilizes the oocytes.

There is an extensive literature on the male reproductive anatomy of brachyuran crabs in general, and of Majoids in particular (Beninger et al. 1988; Diesel 1989; Hinsch and Walker 1974; Moriyasu and Benhalima 1998; Sainte-Marie and Sainte-Marie 1999; Sapelkin and Fedoseev 1981). Spermatogenesis begins in the testes; spermatozoids are enclosed in spermatophores, and together with the seminal fluid are ejaculated through the gonopods. Spermatophore formation occurs while the sperm is surrounded by matrix materials secreted in the testes, efferent ducts or anterior vas deferens, forming the spermatophore wall (Hinsch 1991). In brachyuran crabs, the vas deferens is divided into anterior, median and posterior regions (Benhalima and Moriyasu 2000; Diesel 1989; Johnson 1980). In general, spermatophores are formed in the anterior vas deferens and stored in the median region, while production and storage of seminal fluid occur at the posterior vas deferens.

Libinia spinosa (Milne Edwards, 1834) is a Majoid brachyuran distributed from Espirito Santo (Brazil) to Chubut (Argentina; Boschi 2000; Melo 1996). Although it is one of the crab species most frequently caught by bottom trawlers in the northern Argentine shelf (Boschi 1964), playing an important role in the local marine food webs (Scelzo et al. 2002), no studies have been conducted on its population ecology or reproductive biology. In this study, we characterized the morphology and function of the male reproductive tract and the female spermatheca, and investigated the mode of sperm storage. Results are discussed in the context of brachyuran mating systems and sperm competition.

\section{Materials and methods}

A total of 49 crabs were collected between October 2007 and April 2008 along the coast of Mar del Plata $\left(38^{\circ} \mathrm{S}\right.$, $\left.57^{\circ} 33^{\prime} \mathrm{W}\right)$, Argentina, using trawl nets towed by commercial boats. Individuals were immediately transported to the laboratory. Carapace width $(\mathrm{CW})$ was measured with digital calipers. Following Sal Moyano (2007), only morphometrically mature crabs were used in this study. Males ranged from 53.2 to $83.2 \mathrm{~mm} \mathrm{CW}(N=36)$ and females (four of them ovigerous) from 43.9 to $52 \mathrm{~mm} \mathrm{CW}(N=9)$. Males, and non ovigerous and ovigerous females were kept isolated during 2 weeks in seawater aerated tanks $\left(4 \mathrm{~m}^{3}\right)$ for acclimation, under natural daylight conditions. Crabs were fed squid twice a week and the water was changed weekly.

In order to analyze the content of the spermathecae, series of mating experiments were conducted at the beginning (November 2007) and end (February 2008) of the reproductive season. All males placed in the tanks during the mating trials copulated successfully.

In November, 2007, five non-ovigerous females (group 1) were placed in individual aerated seawater aquaria $(0.4 \times 0.5 \times 0.2 \mathrm{~m})$, each of them with a mature male. Each pair was observed during $2 \mathrm{~h}$, and mating-related behavior was recorded. Successful mating was considered to have occurred when both the female and the male pleons were opened and the male gonopods inserted into the female vulvae. Once mating was completed, individuals were separated and returned to the tanks. Mated females were kept isolated, and data on number of consecutive broods of each one were recorded. Four ovigerous females (group 2) were kept isolated until hatching of their larvae.

In February, 2008, a second series of mating experiments was conducted using both groups of females. The right gonopod of the males was removed using sterilized dissecting scissors, as indicated by Diesel (1989). Group 1 females that mated in that condition were named "re-mated females", while group 2 females that mated only in this second trial were named "mated females". Immediately after mating was completed, the females were killed by placing them in a freezer at $-15^{\circ} \mathrm{C}$ during $\sim 15 \mathrm{~min}$. Right and left spermathecae were dissected for histological study. Sixteen mature males not used in the mating trials were also killed and dissected; samples of the testes and vas deferens were saved for histological study.

Tissue samples were fixed in Bouin's solution during $24 \mathrm{~h}$, dehydrated through a series of graded alcohol solutions, cleared in xylene agent and embedded in paraffin. Serial sections $(5-7 \mu \mathrm{m})$ were cut with a Minot microtome. Sections were mounted on glass slides and stained with standard hematoxylin and eosin for observation under a light microscope.

\section{Results}

Morphology of the testes and vas deferens

Macroscopically, the testes were transparent, flat and highly coiled anteriorly. Histological sections showed that they are composed of lobes surrounded by a fibrous capsule (Fig. 1a). The lobes presented an epithelium characterized by a thin layer of flattened cells with elongated nuclei (Fig. 1b), and were joined by connective tissue. Each lobe contained seminiferous tubules where the sequence of spermatic maturity was observed. Spermatogonia were grouped and located in the periphery of the lobes, forming the germinative center (Fig. 1a, b). Inside those, mitosis of spermatogonia was observed, surrounded by elongated accessory cells (Fig. 1b). Different stages of spermatocytes and spermatozoids were recognized in the rest of the lobes 

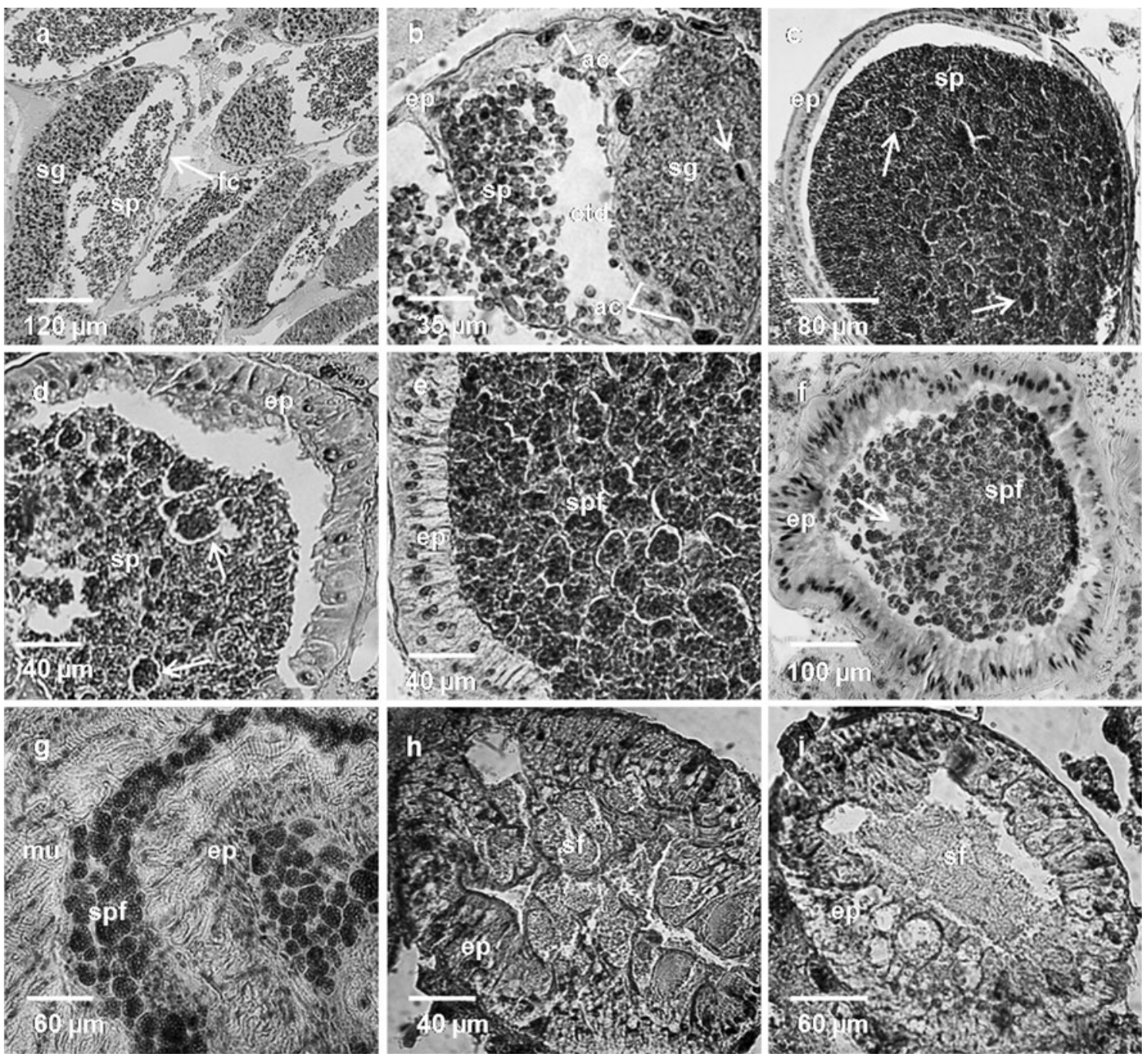

Fig. 1 Libinia spinosa, males. a General view of testicular lobes surrounded by a fibrosous capsule $(f c)$ enclosing groups of spermatids $(s p)$ and spermatogonia $(s g)$. b Detailed structure of a testicular lobe showing the epithelium of flatten cells with elongated nuclei $(e p)$, different stages of sperm maturity $(s p)$, spermatogonia $(s g)$ in mitosis (arrows), accessory cells $(a c)$ and space due the formation of the collecting testicular ducts $(c t d)$. c Detailed structure of the testicular colleting duct showing the cubical epithelium (ep), spermatids $(s p)$ and formation of spermatophores (arrows). d Detailed structure of the anterior vas deferens showing the columnar epithelium (ep), spermatids $(s p)$ and formation of spermatophores (arrows). e Detailed structure of the proximal median vas deferens showing the columnar epithelium ( $e p$ ) enclosing well-developed spermatophores ( $s p f)$. f Detailed structure of ultimate median vas deferens showing the columnar epithelium ( $e p)$ enclosing the spermatophores ( $s p f)$ embedded in a homogeneous seminal fluid (arrows). $g$ Detailed structure of the well-developed musculature of the median vas deferens's last portion. Epithelium $(e p)$, musculature $(m u)$, spermatophores $(s p f)$. h Anterior part of the posterior vas deferens showing the secretory epithelium (ep) enclosing the granular seminal fluid forming droplets $(s f)$. i Terminal part of the posterior vas deferens showing the secretory epithelium (ep) enclosing the granular seminal fluid distributed homogenously $(s f)$

Macroscopically, the vas deferens was white, highly convoluted and enlarged in their posterior region. Histological sections showed the presence of a single layer epithelium of high columnar cells, surrounded by connective and circular muscle tissue layers. Three portions were differentiated as anterior, median and posterior. The anterior vas deferens (AVD) was the portion closest to the testis. Its epithelium presented nuclei in the apical, median and basal positions, and was characterized by the presence of few free (Fig. 1c). 
sperm cells; the bulk of the sperm was enclosed by wrinkled spermatophoric walls (irregular capsule; Fig. 1d). The median vas deferens (MVD) was characterized by the presence of an epithelium with basal and median polymorphic nuclei, and was divided in two regions: proximal and terminal. The proximal region was full of well-developed spermatophores, with smooth and thin spermatophoric walls (regular capsule; Fig. 1e), while the terminal region presented spermatophores embedded in homogeneous seminal fluid (Fig. 1f). The MVD was the main site of storage of well-developed spermatophores. The last portion of the MVD presented an important development of musculature associated with the columnar epithelium (Fig. 1g). The posterior part of the vas deferens (PVD) presented a glandular epithelium, with nuclei in basal, median or apical position, characterized by the presence of secretion products at the apical end of cells. The latter were divided in two portions: an anterior one with granular secretions forming droplets (Fig. 1h), and a terminal one with granular secretion distributed homogeneously (Fig. 1i). No spermatophores were observed in the PVD.

\section{Morphology of the spermatheca}

Macroscopically, the spermathecae look pouch like in shape and are of the ventral type, as the short tube-like oviduct connects to the basal part of the spermatheca in the proximity of the vagina (Fig. 2). In histological sections, the spermatheca showed the presence of two chambers, dorsal and ventral, surrounded by connective and muscle tissue layers (Fig. 3a). The dorsal chamber had a

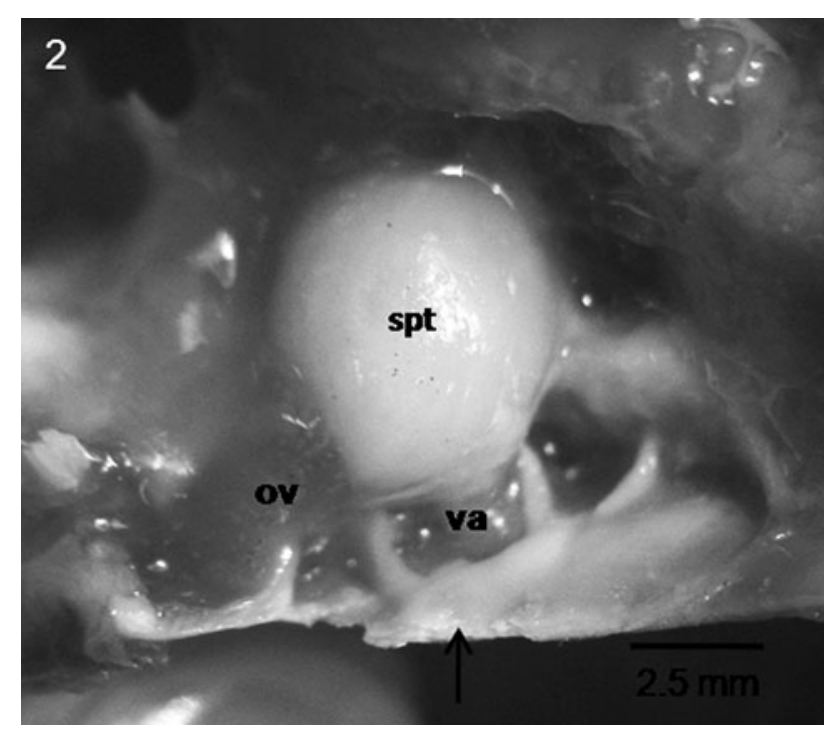

Fig. 2 Libinia spinosa, females. Macroscopical view of the connection between the ovary and oviduct (ov) to the ventral part of the spermatheca $(s p t)$ near its base, in the vicinity of the vagina $(v a)$. The arrow indicates the position of the gonopore multilayered epithelium of columnar cells, lined with holocrine gland cells (Fig. 3a, b). The ventral chamber presented a simple epithelium of columnar cells which were surrounded internally by a cuticular layer (Fig. 3a, c). Oval cells with an elongated nucleus and muscle fibers were observed at the boundary between the two epithelia, and they resembling a relaxed "velum" (Fig. 3a, d). The ventral chamber of the spermatheca is attached to the vagina by muscular fibers (Fig. 3a), and the two are held together by a continuous cuticular layer.

Mating trials: pattern of sperm storage

Females that mated in the first trial (group 1), extruded one $(N=4)$ or two $(N=1)$ batches of eggs $24-48 \mathrm{~h}$ after copulation. The incubation period of the first clutch was 35 weeks, and a female extruded a second clutch after 24 days of hatching of the first clutch. Group 1 females were non-ovigerous when re-mated during the second series of experiments. Eggs from females captured in the ovigerous condition (group 2) hatched during NovemberFebruary; no subsequent spawning was registered while they were kept in isolation.

Right and left spermathecal contents of mated and remated females were differently related to the pattern of sperm storage. Right spermathecae of re-mated females presented two or three discrete sperm masses in the dorsal and ventral chambers (Fig. 3a). The ventral sperm mass corresponded to the new ejaculate, with well-developed spermatozoa characterized by a rounded form and a distinguishable acrosomal core. Dorsal sperm masses were enclosed by spermathecal secretions and corresponded to the old ejaculate, consisting of degenerated sperm characterized by an irregular form, larger size and non-distinguishable acrosomal core. Left spermathecae of re-mated females (not inseminated due to the ablation of the male's right gonopod) presented a single mass of degenerated spermatozoids surrounded by spermathecal secretions restricted to the dorsal chamber (Fig. 4a, b); no sperm masses were observed in the ventral chamber.

Mated females (group 2) presented their right spermathecae, both dorsal and ventral chambers, full of welldeveloped sperm (Fig. 4c, d), while left spermathecae were almost completely filled with spermathecal secretions, and only relicts of degenerated spermatozoids were observed. No intact spermatophores were found inside the spermathecae of any of the experimental females.

\section{Discussion}

In majoid crabs, spermiogenesis has been reported to occur in the testis; sperm cells become spermatozoa and pass to 


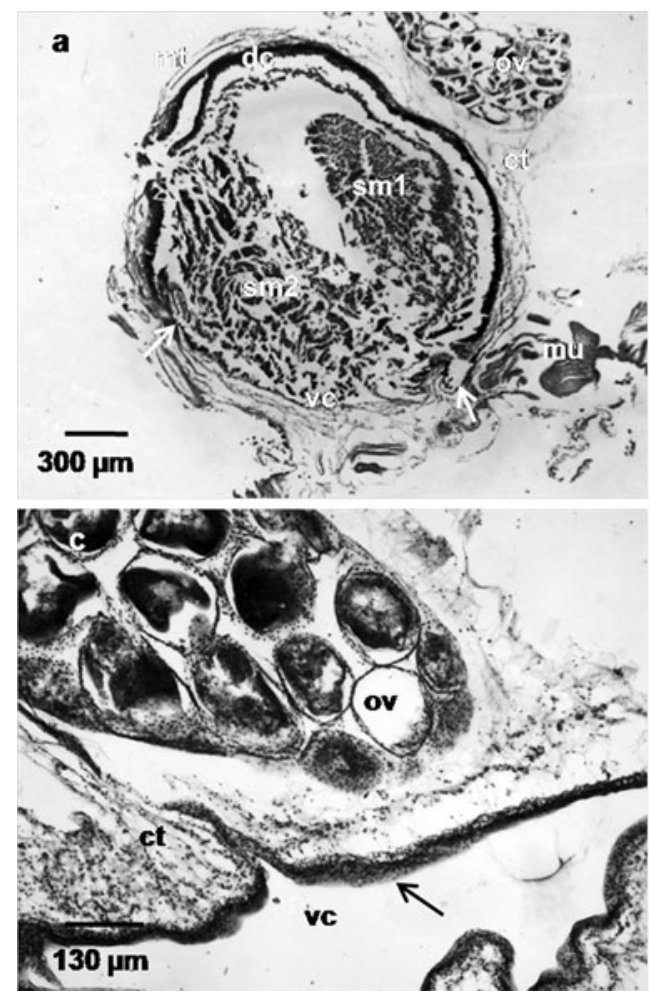

Fig. 3 Libinia spinosa, females. a General view of the spermatheca. Dorsal chamber $(d c)$ and ventral chamber $(v c)$ separated by the relaxed velum (arrows), surrounded by connective ( $c t$ ) and muscle $(\mathrm{mt})$ tissue layers. Spermatic mass $1(\mathrm{sml})$ and spermatic mass 2 $(s m 2)$ composed by spermatozoids and seminal fluid. Ovary (ov) united to the spermatheca by connective tissue $(\mathrm{ct})$. Musculature $(\mathrm{mu})$ that attaches the spermatheca to the vagina. b Detailed structure of the

the anterior vas deferens, where they are enclosed into spermatophores (Beninger et al. 1988; Hinsch 1988; Kon and Honma 1970; Sainte-Marie and Sainte-Marie 1999). Other authors found that formation of spermatophores occurs at the junction of the testis and vas deferens (Moriyasu et al. 2002). In our study, this process was observed to begin in the collecting ducts of the testis, where the spermatophores presented irregular capsules surrounding sperm masses. In general, spermatophores are formed in the AVD and stored in the MVD, while seminal fluid is produced and stored in the PVD. The presence of spermatophores in the last portion of the AVD suggests that their development is completed in that portion. This agrees with the observation by Beninger et al. (1988) that spermatozoa are packed into spermatophores and surrounded by a pellicle which appears to be secreted by the cells lining the anterior vas deferens, proximal to the testis. Hinsch and Walker (1974) described a special function of the MVD related to the absorption of secretion products of the AVD, which initiated compartmentalization of spermatozoa into spermatophores. Benhalima and Moriyasu (2000) reported a peculiar function for the PVD, namely

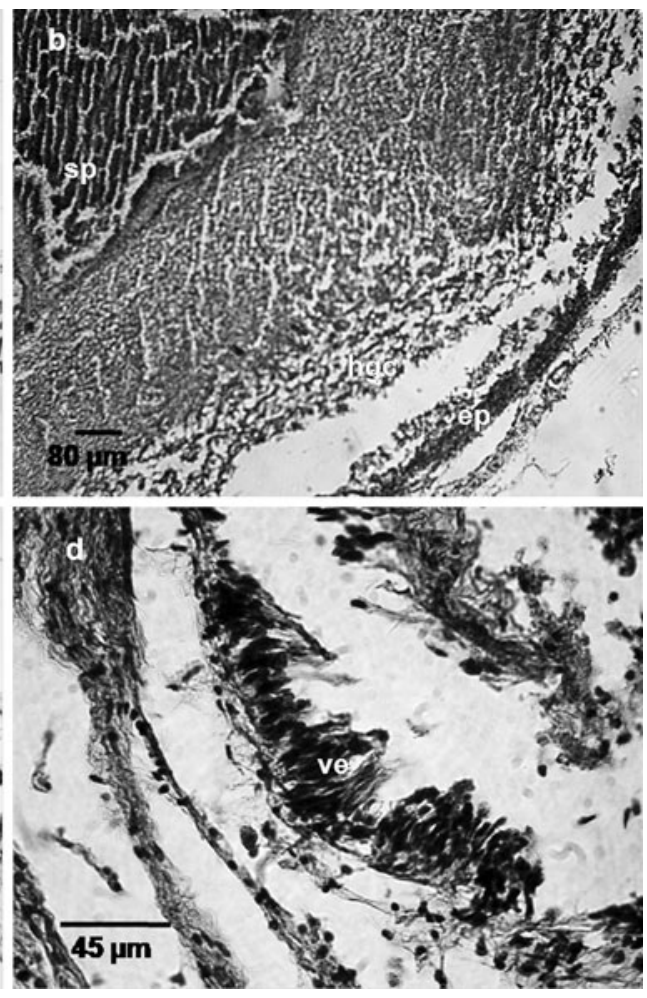

dorsal chamber, showing the multistratified epithelium (ep), lined with holocrine gland cells $(h g c)$, and the presence of spermathecal secretions $(s s)$ and spermatozoids $(s p)$ inside it. $\mathbf{c}$ Detailed structure of the ventral chamber $(v c)$ showing the internal cuticle layer (arrow), connected with the ovary $(o v)$ through connective tissue $(c t)$. d Detailed structure of the velum (ve) showing the oval cells with elongated nucleus

the destruction and resorption of excess spermatophores and spermatozoa, due to the high cellular activity of that portion. We observed that the MVD was full of spermatophores, suggesting that it is the main site of storage, while the typical epithelium of the PVD suggests a secretory role, producing the seminal fluid. The function of the seminal fluid is not well known in decapods. Different authors proposed several presumable functions: (1) it could contribute to the formation of a sperm plug to prevent remating over the short term (Diesel 1991; Hartnoll 1969; Orensanz et al. 1995) and thus prevent sperm competition, (2) fill the ventral chamber of the spermatheca, thus displacing previously stored ejaculates dorsally (Diesel 1990, 1991), (3) act as an antimicrobial agent (Johnson 1980), or (4) provide nutrients to help to maintain spermatozoa within the spermathecae over a prolonged period (Subramoniam 1991). Benhalima and Moriyasu (2000) distinguished two types of seminal fluid, one corresponding to the MVD, providing nutrients, and the other corresponding to the posterior vas deferens, which would function as an antimicrobial agent, catalyze the dehiscence of spermatophoric walls, or destroy excess spermatozoa. Beninger 


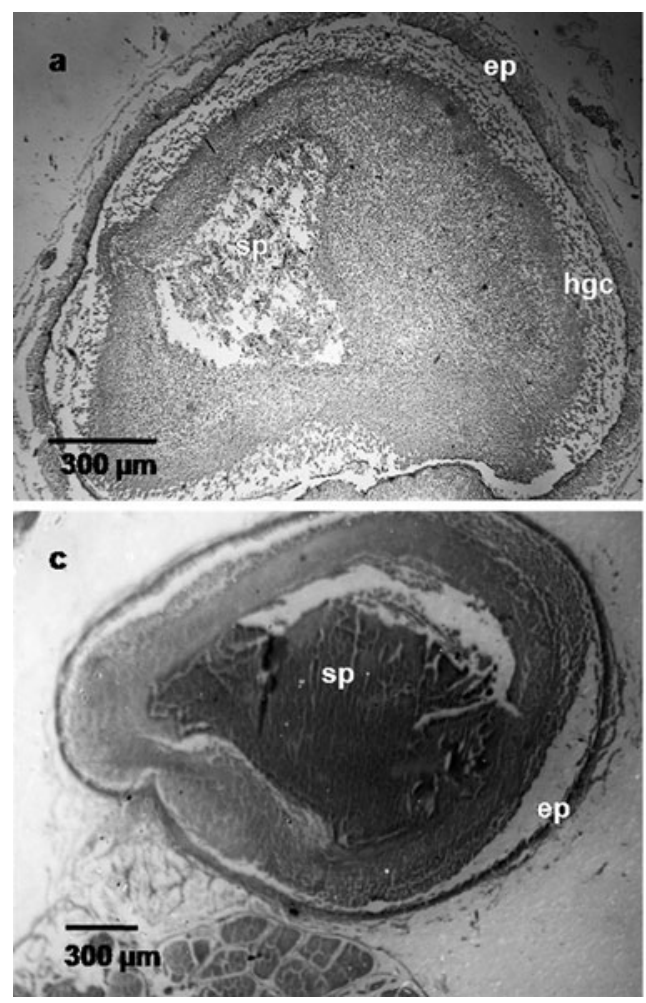

Fig. 4 Libinia spinosa, females. a General view of the spermatheca containing degenerating spermatozoids $(s p)$, enclosed by spermathecal secretions $(s s)$, holocrine gland cells $(h g c)$ and a multistratified epithelium (ep). b Detailed structure of degenerating spermatozoids (arrows) inside spermathecae. $\mathbf{c}$ General view of a spermatheca full of

et al. (1988), working with Chionoecetes opilio (Fabricius, 1788), proposed that, considering the distance and separation of the different portions of the vas deferens, it is likely that active products combine only at the time of ejaculation, forming a "complex organic environment" for spermatophores stored in the female spermatheca. On the contrary, other authors encountered evidence for the same species indicating that the various fluids and secretions may be layered and involved in different functions: serving as a hibernating medium for long-term storage of spermatids, inducing spermiogenesis, and favoring sperm precedence and single paternity in spermathecae with moderate loads (Sainte-Marie and Sainte-Marie 1999; Sainte-Marie et al. 2000). In Libinia spinosa, the important development of the musculature described for the last portion of the MVD would serve to mobilize the spermatophores toward the ejaculatory canal during mating, facilitating the combination of seminal fluid and spermatophores at the moment of ejaculation.

As in other Brachyura, the histological structure of $L$. spinosa's spermathecae was characterized by an elastic dorsal storage chamber, and a ventral cuticle-lined insemination chamber (Beninger et al. 1988; Diesel 1989; Johnson 1980; Ryan 1967; Sainte-Marie and Sainte-Marie

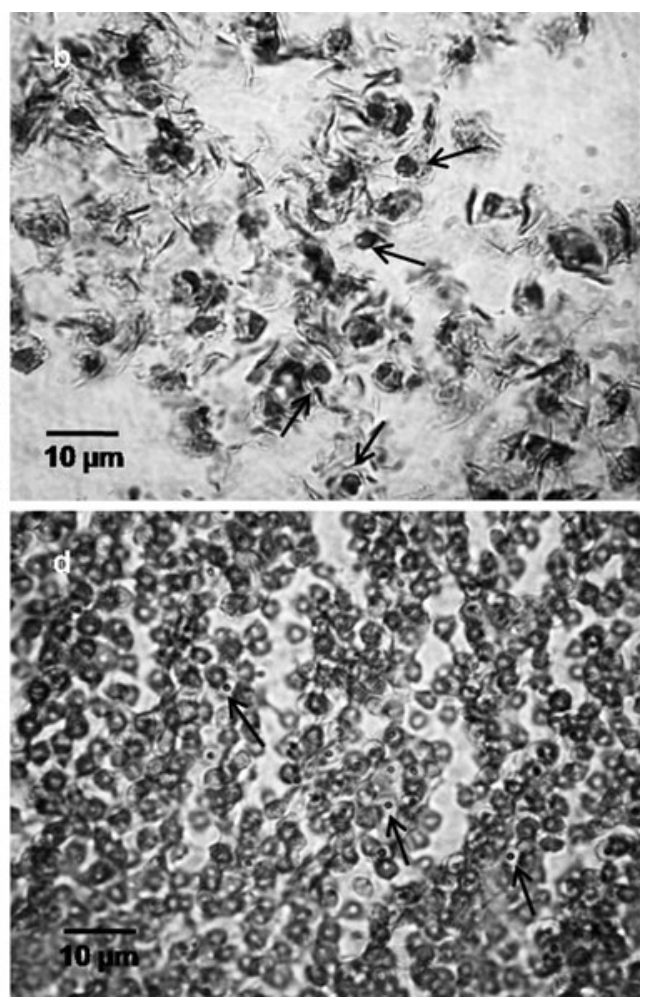

well-developed spermatozoids $(s p)$, surrounded by spermathecal secretions (ss), holocrine gland cells $(h g c)$ and a multistratified epithelium (ep). d Detailed structure of well-developed spermatozoids encountered inside spermathecae, characterized by a rounded form and an acrosomal core distinguishable (arrows)

1998). Although Diesel (1991) suggested the fertilization of eggs occurs in the ventral chamber of the spermatheca, other authors proposed that it could take place in the ovary or externally after extrusion of eggs and sperm (Hinsch 1971; Ryan 1967; Sainte-Marie et al. 2000). Johnson (1980) described for the spermathecae of Callinectes sapidus, the presence of a "cellular sheet" at the boundary of the epithelia lining the two chambers, which could prevent the entry of elements from the external environment and prevent the loss of substances produced by the glandular dorsal epithelium. The existence of a "velum" in the spermathecae of different species of Majoidea was first described by Diesel (1989), who suggested that this "ringlike diaphragm" could regulate sperm use. We observed a similar structure small and relaxed (like an open diaphragm), perhaps due to the fact that females were not ready to spawn. Probable functions of the velum in $L$. spinosa could be suggested: in spermathecae of recently mated females with large loads of fresh sperm occupying both chambers (as seen in the right spermathecae of the "mated females" treatment), it could function as a regulating device, controlling the amount of sperm used during spawning. By contrast, in spermathecae containing fresh and old sperm restricted to the ventral and dorsal chambers, 
respectively (right spermathecae of "re-mated females" treatment), it could allow separation of new and old ejaculates, preventing the entry of old ejaculate into the insemination chamber during spawning. Similar to other Majoids (Beninger et al. 1993; Diesel 1989; Hartnoll 1968; Sainte-Marie and Sainte-Marie 1998), L. spinosa presented a ventral-type spermatheca. Several studies have demonstrated last-male sperm precedence in crabs with ventraltype spermathecae, using either the sterile male technique or the genetic markers (Diesel 1990; Koga et al. 1993; Urbani et al. 1998). In our study, the right spermathecae of "re-mated females" presented ventral masses of sperm characterized by a new ejaculate, while dorsal ones corresponded to old ejaculate, suggesting that the last male to copulate displaces dorsally the old ejaculate from previous males.

In studies conducted in other Majoids, the ejaculate stored inside the spermathecae of mated females consisted of spermatophores (Diesel 1989; Sainte-Marie et al. 2000), while in Cancridas (Burfitt 1980; Hankin et al. 1989; Jensen et al. 1996; Shirley and McNutt 1989) and in the majoid Libinia emarginata (Hinsch 1991), free sperm was observed in the lumen of seminal receptacles shortly after insemination. In our study, no spermatophores were encountered inside the spermathecae of $L$. spinosa females. Instead, free spermatozoids were found embedded in a sperm gel. Since the histological analysis of the male reproductive tract showed that sperm is packed into spermatophores, the more probable explanation is that they are transferred to females during mating and break shortly after insemination. Proposed mechanisms of spermatophore dehiscence include mechanical forces produced by the vaginal wall, water uptake by osmosis upon exposure to seawater (Beninger et al. 1993) and spermatheca secretions breaking down spermatophore walls (Diesel 1989; Ryan 1967; Spalding 1942).

Differences in the location and appearance of the sperm masses between mated and re-mated females suggest the existence of different modes of storage. It has been demonstrated that several species of crabs are able to use stored sperm to fertilize batches of eggs in successive breeding seasons; cases include Majoids (Diesel 1991; Hinsch 1972; Paul 1984), Ocypodoids (Greenspan 1982; Yamaguchi 1998) and Xanthoids (Morgan et al. 1983). It has been proposed that sperm is maintained by nutrients in the seminal fluid, nutrients produced by holocrine gland cells of the spermatheca wall (Subramoniam 1993), female hemolymph, or their own energy stores (Johnson 1980). In L. spinosa, old ejaculates, characterized by degenerated spermatozoids in isolated not mated females during November-February (left spermathecae of "mated and remated females"), was restricted to the dorsal chamber and was surrounded by spermathecal secretions. Although it was not demonstrated experimentally, we suggest that spermathecal secretions are produced by the holocrine gland cells located in the epithelium of the dorsal chamber of the spermathecae, which would facilitate the removal of degraded sperm. The clean spermatheca are likely to provide an environment favoring the success of future inseminations, at which time, new ejaculates occupy the entire ventral and dorsal chambers, as observed by us in females that mated following a period of isolation (right spermathecae of "mated females"). This pattern of sperm storage is similar to that described for $C$. opilio when large loads of ejaculate are deposited by males (Sainte-Marie et al. 2000).

The spermatheca is the site where eventual sperm competition must necessarily take place (Orensanz et al. 1995). In L. spinosa, the presence of multiple ejaculates inside the spermatheca indicates the possibility of sperm competition. Because spermathecae are of the ventral type, last-male sperm is likely fertilize the oocytes: the ventralmost sperm would be the most recent and likely most viable, while sperm of the dorsal-most region is decaying. In several majoid species, it was demonstrated that males transfer spermatophores to the female spermatheca (Beninger et al. 1993; Diesel 1989; Moriyasu and Benhalima 1998; Sainte-Marie and Sainte-Marie 1999). One of the presumed roles of the spermatophoric walls is to function as protection of sperm cells related to long-term storage (Beninger et al. 1993; Sainte-Marie and Sainte-Marie 1999). Benhalima and Moriyasu (1998) found two types of spermatophores differing in the nature of the spermatophoric walls, and suggested that some of them rupture at the time of copulation, while others persist and are stored in the spermathecae, indicating that last-male sperm precedence is ensured by the quantity of spermatophores with immediate dehiscence capacity transferred to the female. No intact spermatophores were found in the spermathecae of L. spinosa females killed soon after mating, suggesting that they are ruptured during copulation. This would favor sperm competition and last-male sperm precedence. The presence of degenerated sperm in the dorsal chamber of the spermatheca and the absence of spermatophores in the ventral region (ejaculate corresponding to recently mated females) suggest that the spermathecae of L. spinosa are not designed for long-term sperm storage.

Acknowledgments We wish to thank Lic. Micaela Vallina for her help with histological sections. We gratefully acknowledge José M. (Lobo) Orensanz for advice and for kindly correcting our English text and to three anonymous reviewers whose critical comments improved this manuscript. This study was funded by the Universidad Nacional de Mar del Plata, Argentina, through a grant (EXA 371/07) to MAG; and by a fellowship from the Comisión de Investigaciones Científicas (CIC) and Consejo Nacional de Investigaciones Científicas y Técnicas (CONICET) to MPSM. The authors declare that they have no conflict of interest. 


\section{References}

Benhalima K, Moriyasu M (1998) Prevalence of bacteria in the spermathecae of female snow crab, Chionoecetes opilio (Brachyura: Majidae). Hydrobiologia 449:261-266

Benhalima K, Moriyasu M (2000) Structure and function of the posterior vas deferens of the snow crab, Chionoecetes opilio (Brachyura, Majidae). Invertebr Reprod Dev 37:11-23

Beninger PG, Elner RW, Foyle TP, Odense PH (1988) Functional anatomy of the male reproductive system and the female spermatheca in the snow crab Chionoecetes opilio (O. Fabricius) (Decapoda: Majidae) and a hypothesis for fertilization. J Crust Biol 8:322-332

Beninger PG, Lanteigne C, Elner RW (1993) Reproductive process revealed by spermatophore dehiscence experiments and by histology, ultrastructure, and histochemistry of the female reproductive system in the snow crab Chionoecetes opilio (O. Fabricus). J Crust Biol 13:1-16

Boschi EE (1964) Los crustáceos decápodos Brachyura del litoral bonaerense (R. Argentina). Bol Inst Biol Mar 6:1-76

Boschi EE (2000) Species of decapod crustaceans and their distribution in the American Marine Zoogeographic Provinces. Rev Invest Des Pesq 13:7-136

Burfitt AH (1980) Glucose phosphate isomerase inheritance in Cancer pagurus $\mathrm{L}$ broods as evidence of multiple paternity (Decapoda: Brachyura). Crustaceana 39:306-310

Diesel R (1989) Structure and function of the reproductive system of the symbiotic spider crab Inachus phalangium (Decapoda: Majidae): Observations on sperm transfer, sperm storage, and spawning. J Crust Biol 9:266-277

Diesel R (1990) Sperm competition and reproductive success in the decapod Inachus phalangium (Majidae) - a male ghost spider crab that seals off rivals sperm. J Zool 220:213-223

Diesel R (1991) Sperm competition and the evolution of mating behavior in Brachyura, with special reference to spider crabs (Decapoda, Majidae). In: Bauer RT, Martin JW (eds) Crustacean sexual biology. Columbia University Press, New York, pp 145163

González-Gurriarán EL, Fernandez JF, Muiño R (1998) Mating and role of seminal receptacles in the reproductive biology of the spider crab Maja squinado (Decapoda: Majidae). J Exp Mar Biol Ecol 220:269-285

Greenspan BN (1982) Semi-monthly reproductive cycles in male and female fiddler crabs, Uca pugnax. Anim Behav 30:1084-1092

Hankin DG, Diamond N, Mohr MS, Ianelli J (1989) Growth and reproductive dynamics of adult female Dungeness crabs (Cancer magister) in northern California. J Cons Int Explor Mer 46:94-108

Hartnoll RG (1968) Morphology of the genital ducts in female crabs. J Linn Soc 47:279-300

Hartnoll RG (1969) Mating in the brachyura. Crustaceana 16:161181

Hinsch GW (1971) Penetration of the oocyte envelope by spermatozoa in the spider crab. J Ultrastruct Res 35:86-97

Hinsch GW (1972) Some factors controlling reproduction in the spider crab Libinia emarginata. Biol Bull 143:358-366

Hinsch GW (1988) Ultrastructure of the sperm and spermatophores of the golden crab Geryon fenneri and a closely related species, the red crab G. quinquedens, from the eastern Gulf of Mexico. J Crust Biol 8:333-339

Hinsch GW (1991) Structure and chemical content of the spermatophores and seminal fluid of reptantian decapods. In: Bauer RT, Martin JW (eds) Crustacean sexual biology. Columbia University Press, New York, pp 290-307

Hinsch GW, Walker MH (1974) The vas deferens of the spider crab, Libinia emarginata. J Morphol 143:1-19
Jensen PC, Orensanz JM, Armstrong A (1996) Structure of the female reproductive tract in the Dungeness crab (Cancer magister) and implications for the mating system. Biol Bull 190:336-349

Johnson PT (1980) Histology of the blue crab, Callinectes sapidus: a model for the Decapoda. Praeger Publishers, New York

Koga T, Henmi Y, Murai M (1993) Sperm competition and the assurance of underground copulation in the sand-bubbler crab Scopimera globosa (Brachyura: Ocypodidae). J Crust Biol 13:134-137

Kon T, Honma Y (1970) Studies on the maturity of the gonads in some marine invertebrates. IV. Seasonal changes in the testes of the Tanner crab. Bull Jpn Soc Sci Fish 36:1028-1033

Melo GAS (1996) Manual de Identificação dos Brachyura (caranguejos e siris) do Litoral Brasileiro. Plêiade, São Paulo

Morgan SG, Goy JW, Costlow JD (1983) Multiple ovipositions from single mating in the mud crab Rhithropanopeus harrisii. J Crust Biol 3:542-547

Moriyasu M, Benhalima K (1998) Snow crabs, Chionoecetes opilio (O. Fabricius, 1788) (Crustacea: Majidae) have two types of spermatophores: hypotheses on the mechanism of fertilization and population reproductive dynamics in the southern Gulf of St. Lawrence, Canada. J Nat Hist 32:1651-1665

Moriyasu M, Benhalima K, Duggan D, Lawton P, Robichaud D (2002) Reproductive biology of male Jonah crab, Cancer borealis Stimpson, 1859 (Decapoda, Cancridae) on the Scotian shelf, northwestern Atlantic. Crustaceana 75:891-913

Ng PKL, Guinot D, Davie PJL (2008) Systema brachyrorum: part 1. An annotated checklist of extant brachyuran crabs of the world. Raffles B Zool 17:1-286

Orensanz JM, Parma AM, Armstrong DA, Armstrong J, Wardrup P (1995) The breeding ecology of Cancer gracilis (Crustacea: Decapoda: Cancridae) and the mating systems of cancrid crabs. J Zool 235:411-437

Paul AJ (1984) Mating frequency and viability of stored sperm in the Tanner crab Chionoecetes bairdi (Decapoda: Majidae). J Crust Biol 4:374-381

Ryan EP (1967) Structure and function of the reproductive system of the crab Portunus sanguinolentus (Herbst) (Brachyura: Portunidae). II. The female system. Proceedings of the symposium on crustacea, Ernakulam. J Mar Biol Assoc India 2:522-544

Sainte-Marie B, Lovrich G (1994) Delivery and storage of sperm at first mating of female Chionoecetes opilio (Brachyura: Majidae) in relation to size and morphometric maturity of male parent. $\mathrm{J}$ Crust Biol 14:508-521

Sainte-Marie G, Sainte-Marie B (1998) Morphology of the spermatheca, oviduct, intermediate chamber, and vagina of the adult snow crab (Chionoecetes opilio). Can J Zool 76:1589-1604

Sainte-Marie G, Sainte-Marie B (1999) Reproductive products in the adult snow crab (Chionoecetes opilio). I. Observations on spermiogenesis and spermatophore formation in the vas deferens. Can J Zool 77:440-450

Sainte-Marie G, Sainte-Marie B, Sévigny JM (2000) Ejaculatestorage patterns and the site of fertilization in female snow crabs (Chionoecetes opilio; Brachyura, Majidae). Can J Zool 78:19021917

Sal Moyano MP (2007) Biología reproductiva de Libinia spinosa (Crustacea: Decapoda: Majidae) en el ambiente costero de Mar del Plata: caracteres morfológicos asociados al comportamiento reproductivo. Dissertation, Universidad Nacional de Mar del Plata

Sapelkin AA, Fedoseev VY (1981) Structure of the male reproductive system of Tanner crabs. Biol Morya 7:37-43

Scelzo M, Martinez Arca J, Lucero N (2002) Diversidad, densidad y biomasa de la macrofauna componente de los fondos de pesca "camarón-langostino" frente a mar del Plata, Argentina (19981999). Rev Invest Des Pesq 15:43-66 
Shirley TC, McNutt L (1989) Precocious mating and trans-molt sperm retention by female Dungeness crabs. Am Zool 29:131A Spalding JF (1942) The nature and formation of the spermatophore and sperm plug in Carcinus maenas. Q J Microsc Sci 83:399423

Subramoniam T (1991) Chemical composition of spermatophores in decapods crustaceans. In: Bauer RT, Martin JW (eds) Crustacean sexual biology. Columbia University Press, New York, pp 308321
Subramoniam T (1993) Spermatophores and sperm transfer in marine crustaceans. Adv Mar Biol 29:129-214

Urbani N, Sainte-Marie B, Sévigny JM, Zadworny D, Kuhnlein U (1998) Sperm competition and paternity assurance during the first breeding period of female snow crab (Chionoecetes opilio) (Brachyura: Majidae). Can J Fish Aquat Sci 55:1104-1113

Yamaguchi T (1998) Longevity of sperm of the fiddler crab Uca lacteal (de Haan 1853) (Decapoda: Brachyura: Ocypodidae). Crustaceana 71:712-713 